\title{
PLACEMENT OF CUBIPOD ARMOR UNITS IN SAN ANDRÉS BREAKWATER (PORT OF MALAGA, SPAIN)
}

\author{
Antonio Corredor ${ }^{1}$, Moisés Santos ${ }^{1}$, M. Esther Gómez-Martín ${ }^{2}$ and Josep R. Medina ${ }^{3}$
}

Single- and double-layer Cubipod armors were considered in the preliminary design of the San Andrés breakwater (Port of Malaga, Spain). 2D and 3D hydraulic stability and overtopping tests for single- and double-layer Cubipod armors were carried out as well as realistic 3D placement tests using a small-scale crawler crane and pressure clamps. The low bearing capacity of the sea bottom and the uncertainty about breakwater settlements were the key factors to use the double-layer Cubipod armor in the final design. Optimum placement grids are different for straight trunk, curved trunk and roundhead designs; the dimensionless plan curvature is the key factor for optimum placement grids. The bottom Cubipod armor layer placed on 1-tonne quarrystone was better placed with lower porosity than the upper Cubipod layer placed on 6-tonne $\left(2.6 \mathrm{~m}^{3}\right)$ Cubipods. The on-going prototype placement method with a crawler crane and pressure clamps is similar to that used in the small-scale tests.

Keywords: mound breakwater; concrete armor unit; Cubipod; placement; hydraulic stability; overtopping.

\section{INTRODUCTION}

The Port of Malaga is situated on the Mediterranean, on the Southern coast of the Iberian Peninsula, in a natural bay $\left(4^{\circ} 25^{\prime} \mathrm{W}\right.$ and $\left.36^{\circ} 43^{\prime} \mathrm{N}\right)$. The Port of Malaga is currently modernizing its facilities and creating new spaces southwards. Amongst other projects, the new San Andrés breakwater is being constructed by SATO (OHL Group) to provide shelter for new port facilities. The San Andrés breakwater is located on the southern part of the port of Malaga in an area of sea bottom with low bearing capacity and a relevant uncertainty about long-term breakwater settlements.

(a)

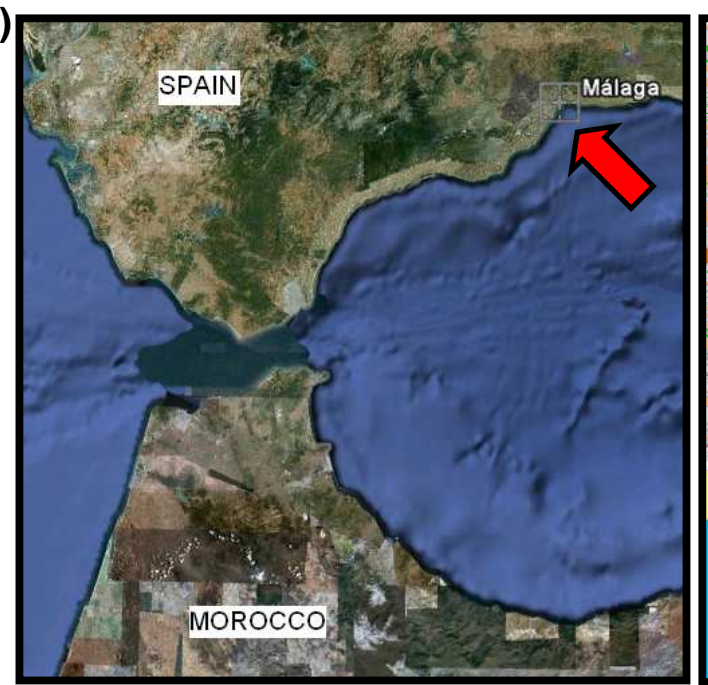

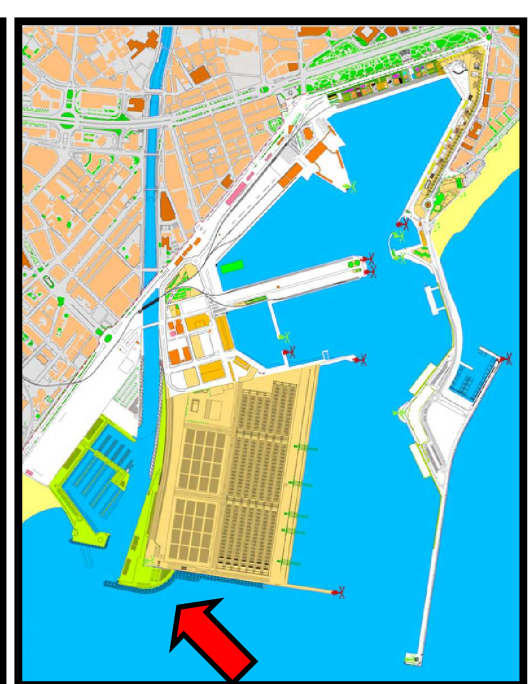

(b)

Figure 1. Construction site: (a) Málaga location in the Mediterranean coast and (b) port layout.

The first objective of this project was to construct a reliable breakwater with a flexible enough performance to avoid geotechnical failure modes caused by low soil bearing capacity and high settlements. Furthermore, the breakwater design had to provide acceptable overtopping rates, low construction costs and concrete consumption as well as high hydraulic stability. To fulfill the particular conditions for this area, the optimal solution for this breakwater had to: (1) improve geotechnical stability conditions, (2) adapt to larger settlements in the long term, (3) balance hydraulic stability and concrete consumption and (4) minimize overtopping.

In this paper, the preliminary San Andrés breakwater design with single- and double-layer armors and different concrete armor units (CAUs) are discussed. The 2D and 3D hydraulic stability and overtopping tests of single- and double-layer Cubipod armors are described. These tests were carried out at the wave flume of the Universidad Politécnica de Madrid (UPM) and a wave basin of the

\footnotetext{
${ }^{1}$ SATO (OHL Group), Paseo de la Castellana 259-D, Torre Espacio, Madrid, 28046, Spain

2 Universidad de Alicante, Dept. of Construction, Carretera de Sant Vicent del Raspeig s/n, Alicante, 03690, Spain

${ }^{3}$ Universitat Politècnica de València, Laboratory of Ports and Coasts, Camino de Vera s/n, Valencia, 46023, Spain
} 
Spanish Centro de Estudios y Experimentación de Obras Públicas (CEDEX). Thirdly, the block yard is described briefly and the realistic placement tests using small-scale crawler cranes, carried out at the wave basin of the Universitat Politècnica de València (UPV), are analyzed with the optimum placement grids for the San Andrés breakwater. Finally, the Cubipod placement works at the prototype scale are described.

\section{SINGLE- AND DOUBLE-LAYER ARMORS}

Compared to conventional double-layer armors, single-layer armors significantly reduce the concrete consumption and sometimes construction costs (see Dupray and Roberts, 2009). However, failure functions of double-layer armors are less sensitive to large breakwater settlements and poor CAU placement. Massive CAUs (cubes, Cubipods, etc.) with random placement, which resist by gravity and lateral friction, adapt better to settlements than slender CAUs that resist by interlocking. If considerable differential settlements occur, the armor layers with CAUs resisting by interlocking may undergo uncontrolled breakages and may lose their original interlocking and hydraulic stability, thus becoming unreliable armors in the long term. The first San Andrés breakwater design for bidding was a conventional double-layer 10-tonne and 21-tonne cube armor on a $\mathrm{H} / \mathrm{V}=2 / 1$ slope with a $40 \mathrm{~m}$ wide berm to improve geotechnical stability. The design conditions were $\{\mathrm{Hs}[\mathrm{m}]=5.6, \mathrm{Tp}[\mathrm{s}]=12.0$ and $\Delta \mathrm{h}[\mathrm{m}]=1.0\}$.

At a preliminary design stage, single-layer armors with interlocking CAUs were disregarded, and a single-layer massive CAU Cubipod armor was considered. Single-layer Cubipod armors have shown a significant resilience and self-repairing behavior in small-scale tests; if a specific unit is extracted, the neighboring CAUs tend to move slightly to close the gap and prevent progressive failure. Furthermore, structural strength is guaranteed because of the high resistance to impacts (see Medina et al., 2011).

Specific 2D hydraulic stability tests were conducted at the UPM wave flume (E:1/40). The 8-tonne Cubipod single-layer armor showed no damage under the design wave storm. The hydraulic stability was much higher than required, and overtopping rates were also lower than the initial double-layer cube armor design; however, the wave flume bottom was rigid and sea bottom at the construction site is not. The model effect associated to the long-term settlement of the sea bottom meant the rejection of the single-layer Cubipod armor for the San Andrés breakwater. Therefore, double-layer armors with massive CAUs were favored given the low bearing capacity of the sea bottom at the construction site.

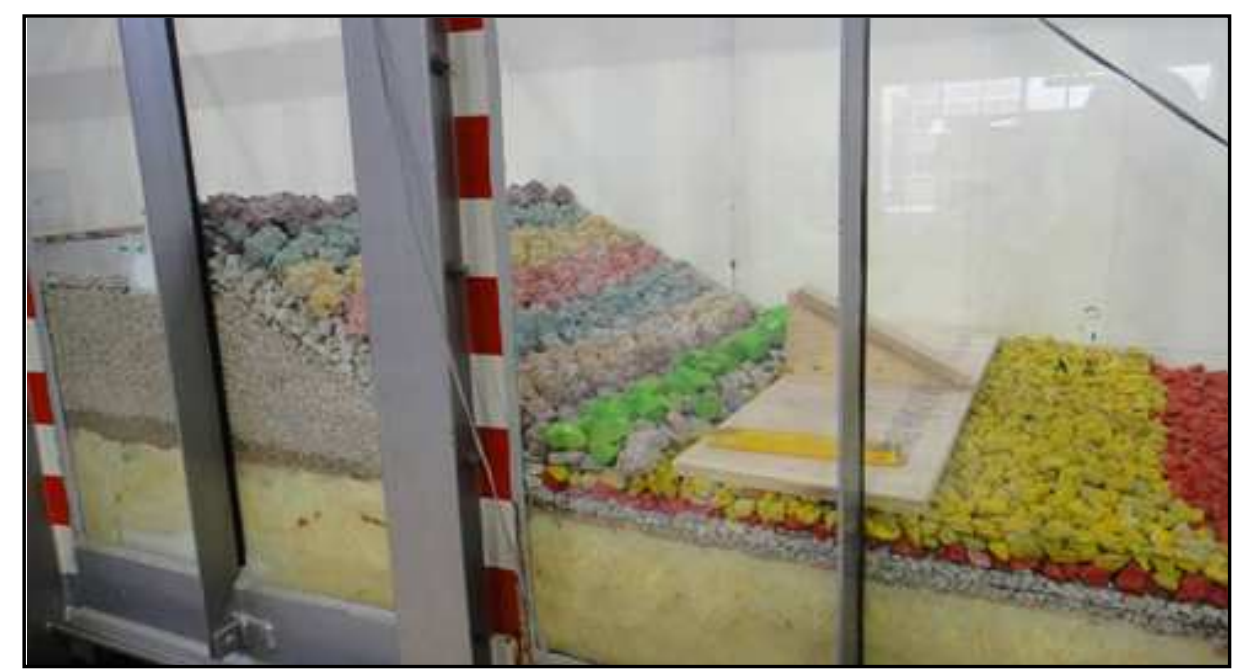

Figure 2. Single-layer Cubipod armor in 1/40 scaled model at UPM wave flume.

Conventional cube armors experienced Heterogeneous Packing (HeP) and face-to-face fitting as reported by Gómez-Martín and Medina (2007 and 2008); if armor settlement is significant, the HeP problem worsens as cubes try to adapt the differential settlements and slope changes. On the contrary, Cubipod armors have high construction reliability because they tend to adapt to slope deformations while maintaining their randomness and thus a rather homogeneous porosity. Furthermore, Cubipod CAUs offer greater friction with the secondary layer, avoiding abrupt armor slides. Therefore, a doublelayer 6-tonne $\left(2.6 \mathrm{~m}^{3}\right.$ and $\left.\gamma_{\mathrm{r}}=2.3 \mathrm{t} / \mathrm{m}^{3}\right)$ Cubipod armor on a $\mathrm{H} / \mathrm{V}=2 / 1$ slope was considered for the final design phase of the San Andrés breakwater. 
CAU weights ( $\mathrm{W}[\mathrm{t}]=15$ for roundhead and $\mathrm{W}[\mathrm{t}]=6$ for trunk) were calculated to provide higherthan-usual safety factors considering $K_{D}=28$ for trunk and $K_{D}=7$ for roundhead as reported by Medina et al. (2010b). Not only was hydraulic stability considered, but also economic and logistic factors because a significant increase in CAU weight may only generate a slight higher construction cost. Finally, 3D hydraulic stability and overtopping tests, which were carried out at CEDEX, proved that 15tonne Cubipods in roundhead were overdesigned. 6-tonne double-layer armors proved to be large enough to resist more than the design conditions, both in trunk and roundhead. Fig. 3 shows a view of the CEDEX wave basin $(45.0 \times 6.5 \times 2.0 \mathrm{~m})$ with the 1/36 small-scale model of the San Andrés breakwater. Hydraulic stability tests showed that the roundhead and the straight alignment have no damage (0\%) for $\mathrm{H}_{\mathrm{m} 0}[\mathrm{~m}]=5.7$, while the curve section has low damage $(<4 \%)$ for $\mathrm{H}_{\mathrm{m} 0}[\mathrm{~m}]=5.7$.

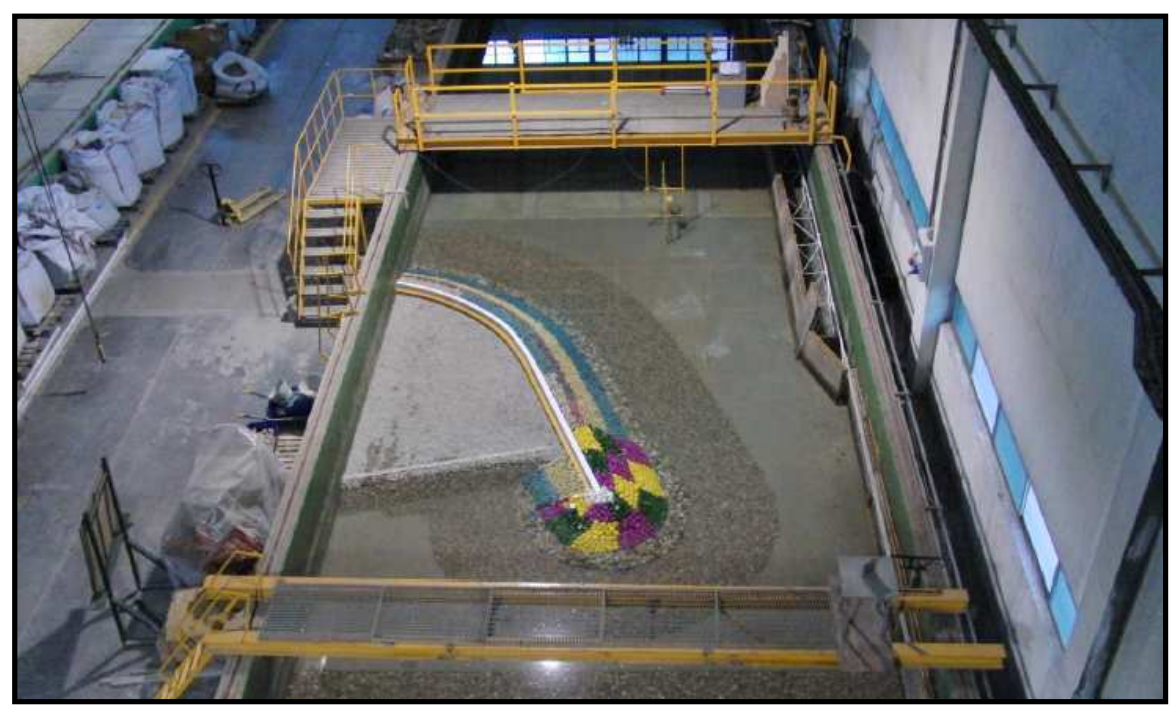

Figure 3. Double-layer Cubipod armor in 1/36 scaled model at CEDEX wave basin.

Figs. 4 and 5 show the cross section of the San Andrés breakwater which has a double-layer 6tonne Cubipod armor both for the trunk and roundhead. The breakwater crest elevation in the trunk and roundhead sections were (prototype dimensions) $\mathrm{Rc}[\mathrm{m}]=+6.50$ and +5.00 , respectively. In both sections, a $40 \mathrm{~m}$ wide berm was constructed on the sea bottom with a water depth $\mathrm{h}[\mathrm{m}]=6.75 \mathrm{~m}$.

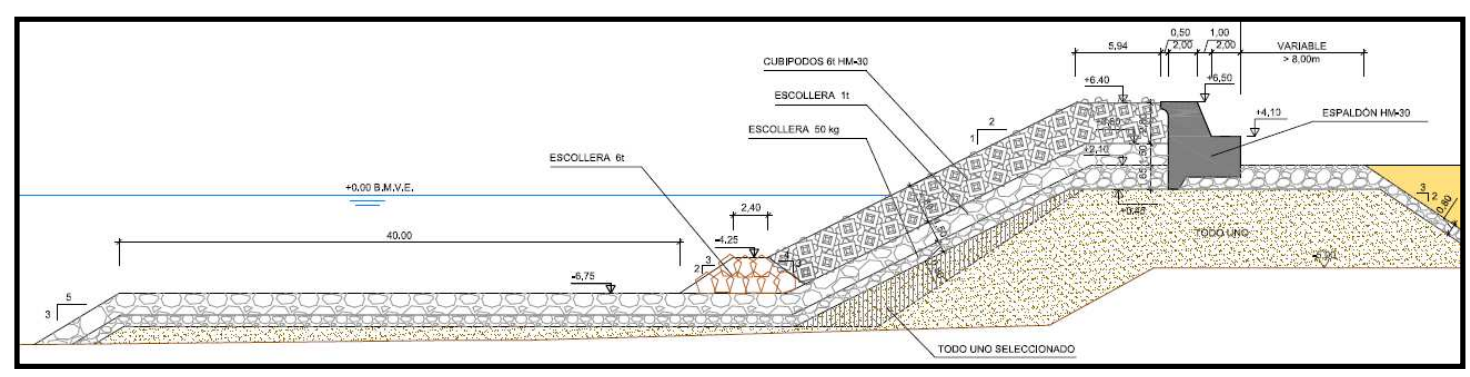

Figure 4. San Andrés breakwater trunk section (double-layer 6-tonne $\left[2.6 \mathrm{~m}^{3}\right]$ Cubipod armor).

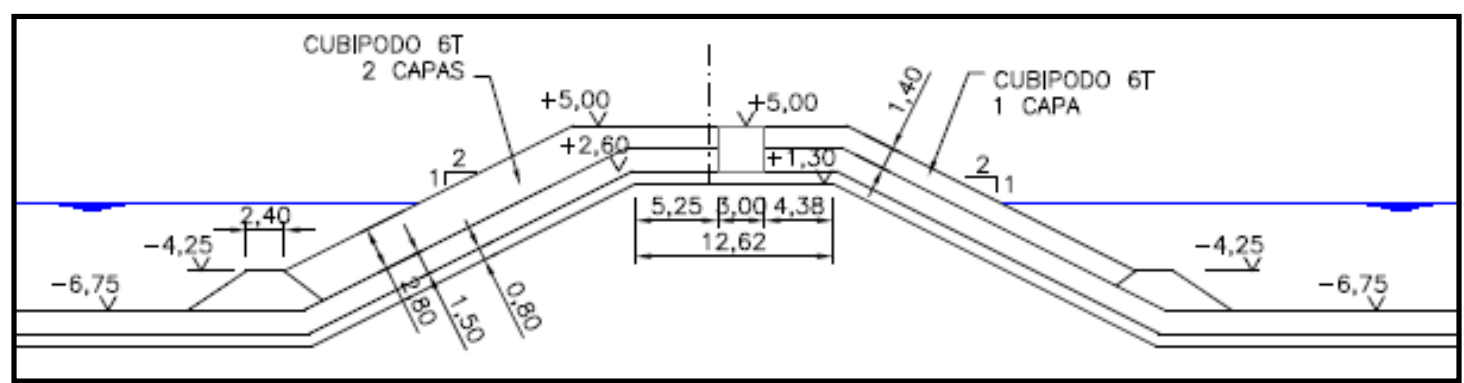

Figure 5. Final San Andrés breakwater roundhead section (double-layer 6-tonne Cubipod armor). 
The Cubipod CAU was chosen for the San Andrés breakwater as the optimal unit to be placed randomly in a double-layer and on a 2/1 slope. Fig. 6 shows the San Andrés breakwater armored with 6tonne Cubipods both in the trunk and roundhead.

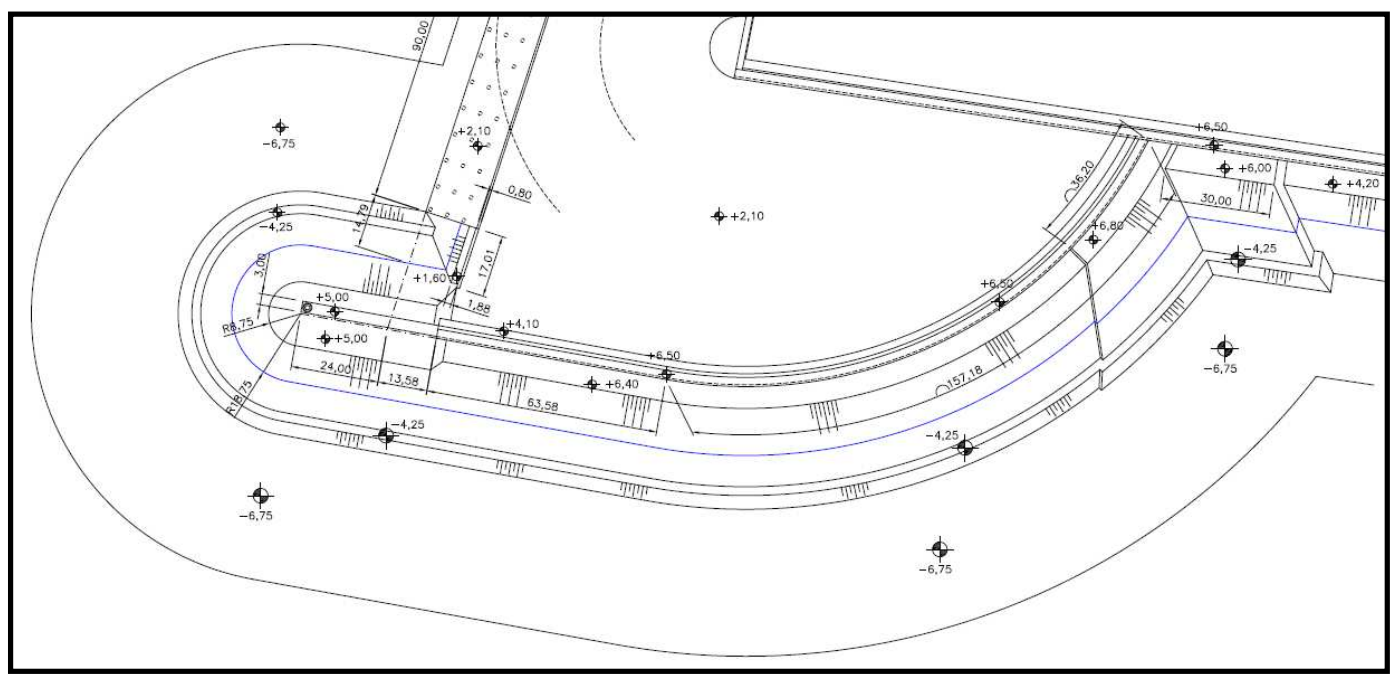

Figure 6. Final design of San Andrés breakwater.

\section{MANUFACTURE AND STACKING CUBIPODS IN THE BLOCK YARD}

Cubipod CAUs are easy to manufacture and stack in the block yard. Each vertical mold, designed by SATO technicians, produces 2 units/day (see Corredor et al., 2008). Additionally, the high structural strength of the massive Cubipod (see Medina et al., 2011) means that multi-layer stacking at the block yard is possible with highly efficiency and handling safety similar to conventional cubic blocks. Figs. 7 and 8 show the San Andrés breakwater block yard with more than 5,000 6-tonne $\left(2.6 \mathrm{~m}^{3}\right)$ Cubipods stacked in five layers and closed arrangement (30\% porosity). A linear production yard with an elevated platform was used with direct pouring from the truck mixer. The daily production was 46 6-tonne Cubipods using 23 formworks.

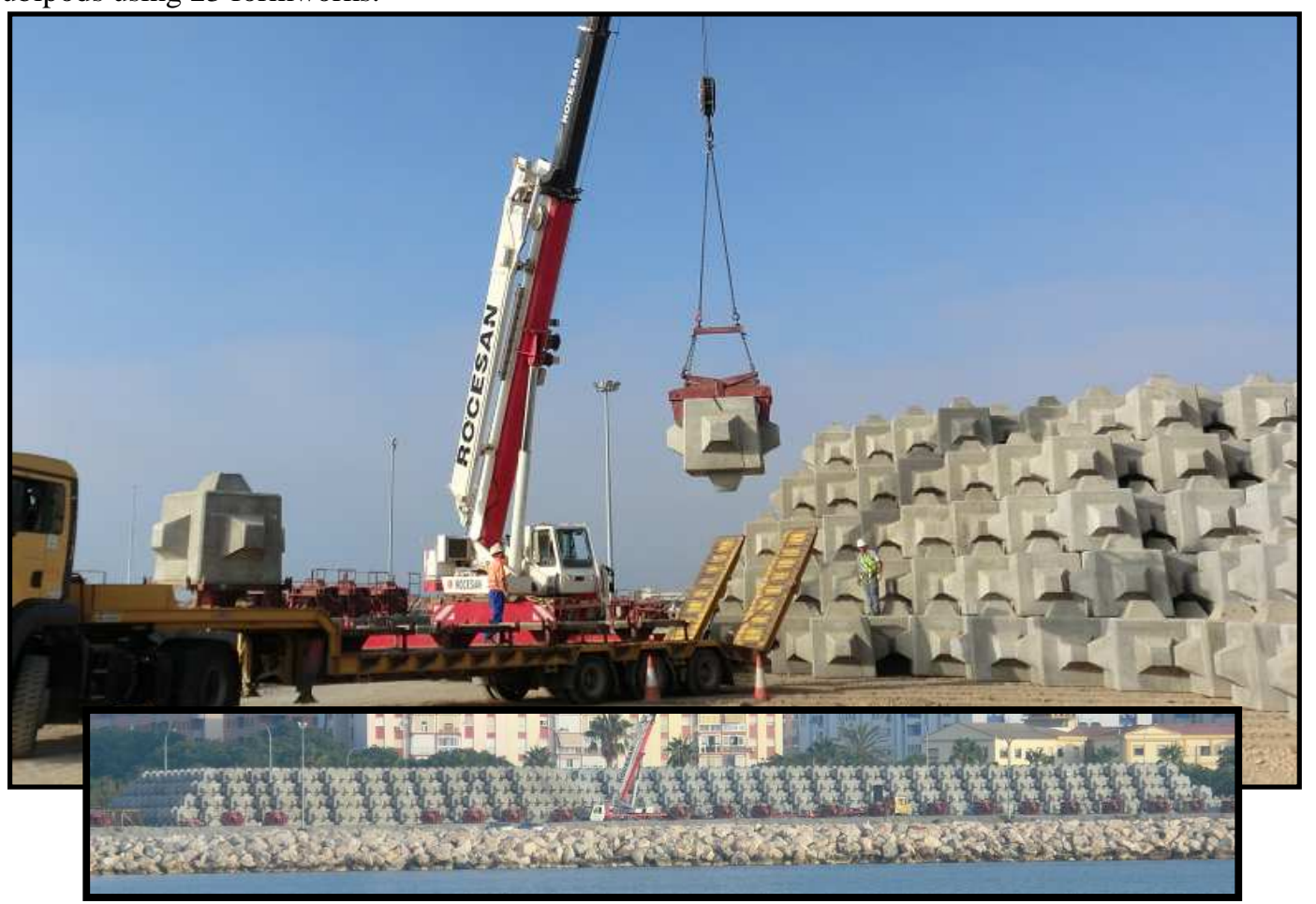

Figure 7. Terrestrial views of the block yard of San Andrés breakwater. 


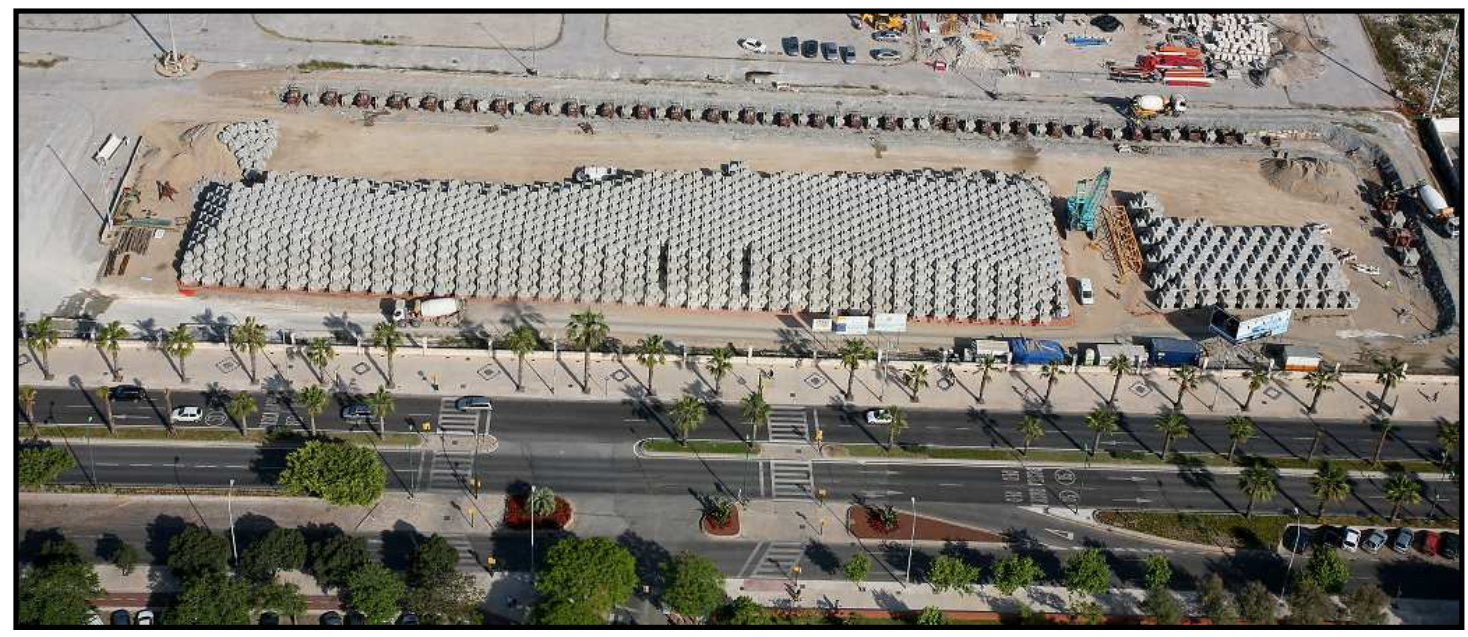

Figure 8. Aerial view of the block yard of San Andrés breakwater.

\section{PLACEMENT OF CUBIPODS WITH CRAWLER CRANES AND PRESSURE CLAMPS}

Armor porosity (p\%) of mound breakwaters affects hydraulic stability, breakwater logistics, construction costs, etc.; however, armor porosity of randomly-placed CAUs is not easy to quantify and rarely taken into consideration during the design process. Most engineering manuals recommend specific nominal armor porosities $(\mathrm{P} \%)$ and layer coefficients $\left(\mathrm{k}_{\Delta}\right)$ for different CAUs; nevertheless, only the placing density $\left(\varphi\left[\right.\right.$ units $\left.\left./ \mathrm{m}^{2}\right]\right)$, directly related to both $\mathrm{P} \%$ and $\mathrm{k}_{\Delta}$, can be controlled with the appropriate placement grid during the construction process. To avoid misunderstandings when using $\mathrm{k}_{\Delta} \neq 1.00$ (see Medina et al., 2010a), armor porosity is defined here as $\mathrm{p} \%=100 \%-\mathrm{k}_{\Delta}[1-\mathrm{P} \%]$. Armor porosity $(\mathrm{p} \%)$ is directly related to placing density $(\varphi)$ and packing density $(\Phi)$; it must be controlled and measured in small-scale physical tests as well as at prototype scale.

The construction of armor layers in small-scale experiments is usually done in the best conditions (dry construction by hand, perfect underwater view, easy correction, etc.). However, real construction is not so easy; CAUs are placed using crawler cranes equipped with pressure clamps or slings, with poor underwater viewing, wind and waves. In order to define the optimum placement grids for Cubipods in the San Andrés breakwater, realistic 3D small-scale placement tests were carried out in the UPV wave basin $(15.0 \times 7.0 \times 0.5 \mathrm{~m})$ with the methodology proposed by Medina et al. (2010a). To compare different diamond shape placement grids, small-scale crawler crane equipped with pressure clamps similar to that operated at prototype scale was used to simulate the construction process. Different optimum placement grids were found for straight trunk, curve trunk and roundhead. Curved trunk and roundhead required special progressive grids which depended on dimensionless curvature. Small-scale tests revealed that bottom armor layers placed on the 1-tonne quarrystone were better placed than the upper armor layer placed on 6-tonne Cubipods (lower porosity for the bottom layer and higher porosity for the upper layer).

Small-scale 3D placement tests for Cubipod CAUs at 1/36 scale were conducted using a crawler crane with pressure clamps (Fig. 9). Cubipod units were placed on a $H / V=2 / 1$ slope with the appropriate placement grid in each area (i.e. straight trunk: $a=1.50 \mathrm{Dn}$ and $\mathrm{b}=1.05 \mathrm{Dn}$ ) in order to obtain an average armor porosity of $\mathrm{p} \% \approx 41 \%$.

At prototype scale, the placement method was similar to small-scale. A crawler crane was used with a GPS positioning system at the head and a double pressure clamp to lift the Cubipod from the truck and place it on the breakwater slope. Fig. 10 shows the crawler crane transfering a 6-tonne Cubipod from the truck to the armor slope, to a place in the corresponding underwater position. The 1-tonne quarrystone filter layer and the 6-tonne toe berm were placed before the armor was initiated. The first row of CAUs is placed along the toe berm and the following rows later from the bottom to the crest. The breakwater is protected first with a single-layer Cubipod armor and later the second layer of Cubipods will be placed on top to form the designed double-layer 6-tonne Cubipod armor. 


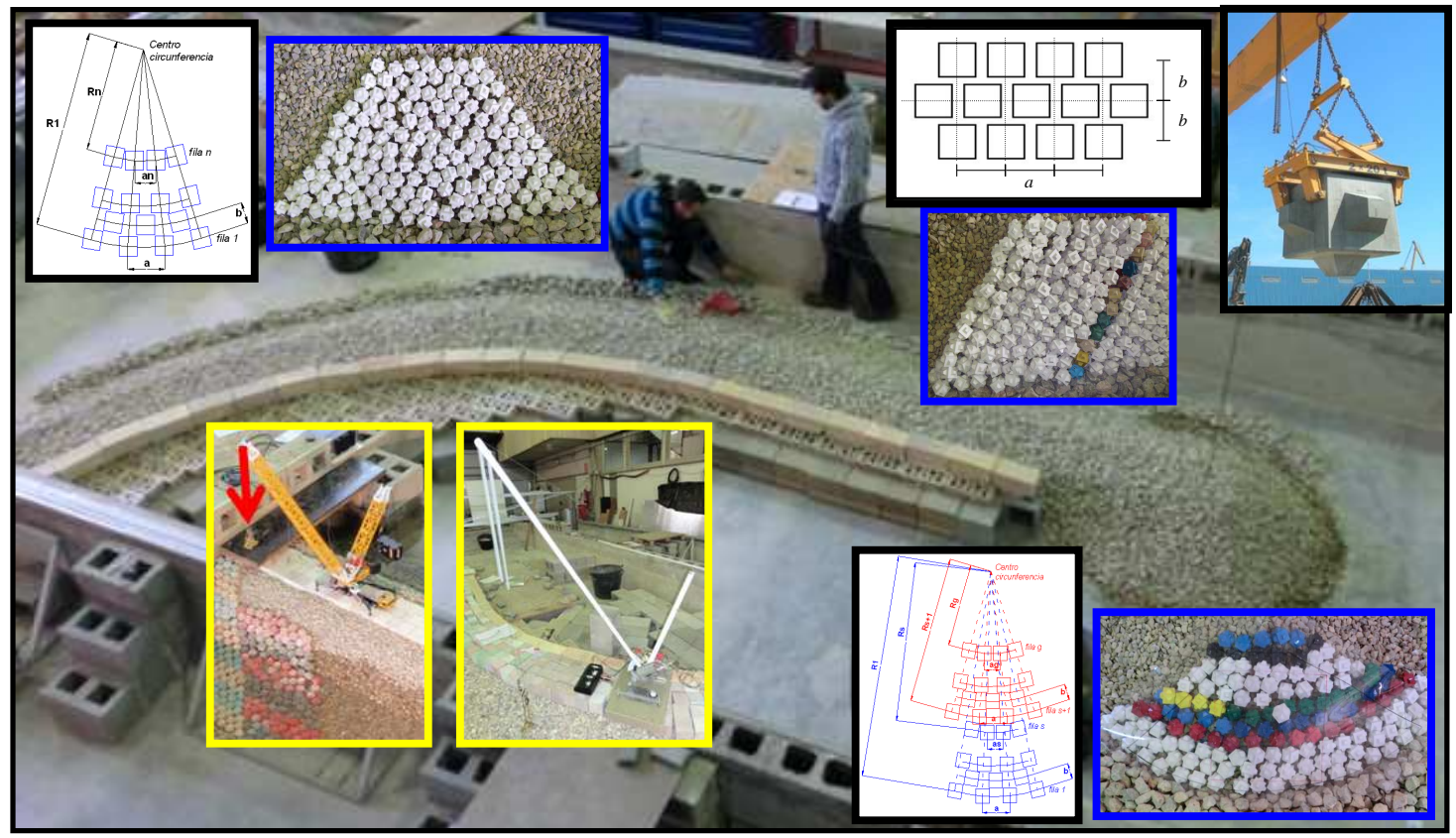

Figure 9. Cubipod placement grids and the small-scale crawler crane with pressure clamps.

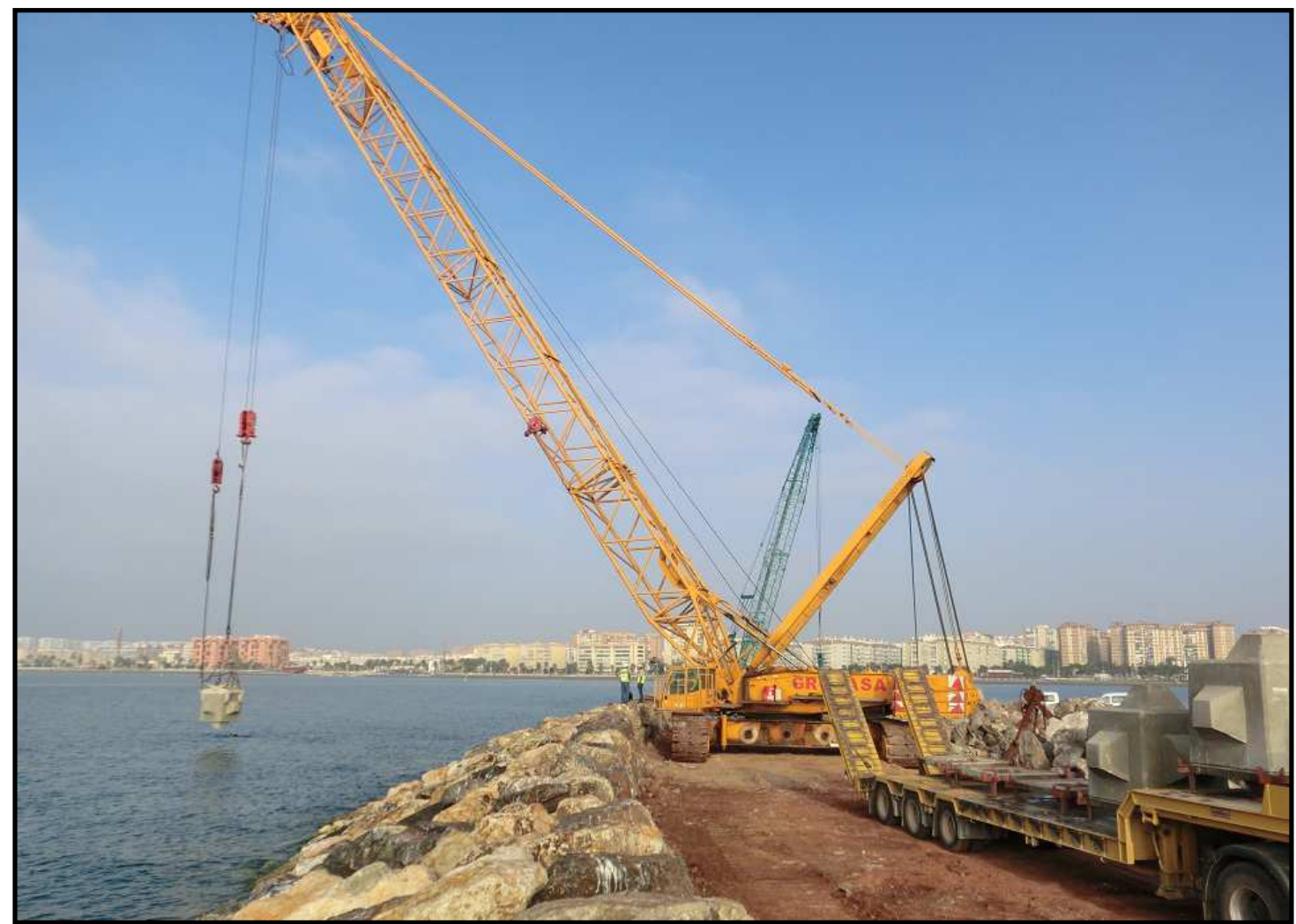

Figure 10. Crawler crane with pressure clamps placing a 6-tonne $\left(2.6 \mathrm{~m}^{3}\right)$ Cubipod on the breakwater slope.

Fig. 11 shows an aerial view of the San Andrés breakwater under construction. The yellow crawler crane is placing the first layer of 6-tonne Cubipods in the trunk, while the blue crawler crane is constructing the berm and filter layer of the roundhead. 


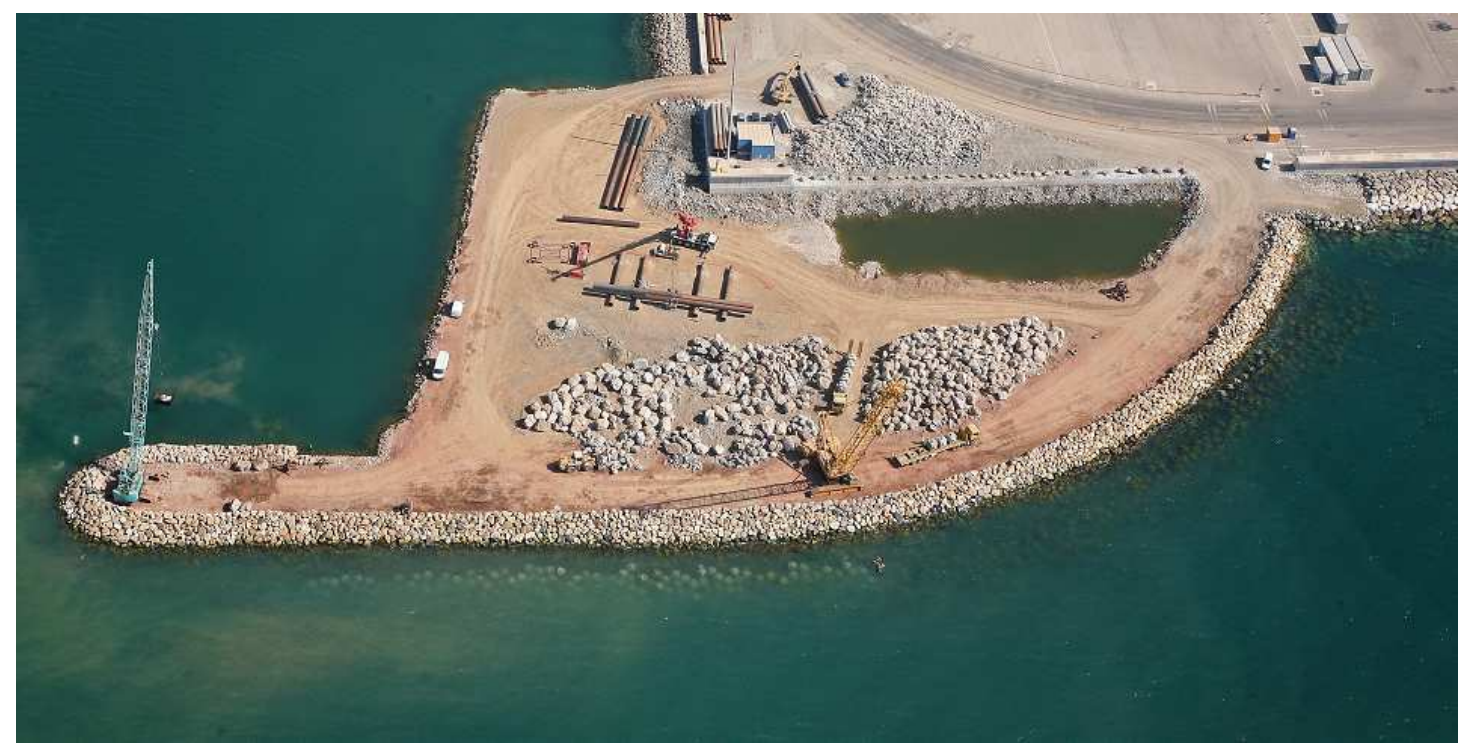

Figure 11. Aerial view of the San Andrés breakwater under construction.

\section{SUMMARY AND CONCLUSIONS}

The new San Andrés breakwater is currently being constructed by SATO (OHL Group) to provide shelter for the new Malaga Port facilities. The San Andrés breakwater is located in an area of sea bottom with low bearing capacity and a relevant uncertainty about long term breakwater settlements. The first breakwater design for bidding was a conventional double-layer 10-tonne $\left(4.3 \mathrm{~m}^{3}\right)$ and 21 tonne $\left(9.1 \mathrm{~m}^{3}\right)$ cube armor on a $\mathrm{H} / \mathrm{V}=2 / 1$ slope with a $40 \mathrm{~m}$ wide berm to improve geotechnical stability. The design conditions were $\{\mathrm{Hs}[\mathrm{m}]=5.6, \mathrm{Tp}[\mathrm{s}]=12.0$ and $\Delta \mathrm{h}[\mathrm{m}]=1.0\}$.

Different breakwater alternative designs with single- and double-layer armors and various concrete armor units (CAUs) were considered. In this project, at a preliminary design stage, single-layer armors with interlocking CAUs were disregarded because differential settlements might cause uncontrolled breakages of interlocked units. A single-layer massive CAU Cubipod armor was considered given its significant resilience and self-repairing behavior when a specific unit is extracted along with its high structural strength and resistance to impacts. 2D hydraulic stability and overtopping tests (1/40 scale) carried out at the UPM wave flume proved that a single-layer 8-tonne Cubipod armor resisted above the design conditions. However, the uncertain model effect associated to the long-term settlement of the sea bottom at the construction site also meant the rejection of the single-layer Cubipod armor for the San Andrés breakwater. Double-layer armors with massive CAUs were favored because of the low bearing capacity of the sea bottom at the construction site.

Conventional cube armors experience Heterogeneous Packing (HeP) and face-to-face fitting, especially if armor settlement is significant; on the contrary, Cubipod armors have high construction reliability because they tend to adapt to slope deformations while maintaining their randomness. 3D hydraulic stability and overtopping tests (1/36 scale) carried out at the CEDEX wave basin proved that single- and double-layer 6-tonne $\left(2.6 \mathrm{~m}^{3}\right)$ Cubipod armor in trunk and roundhead resisted above the design conditions.

More than 5,000 6-tonne $\left(2.6 \mathrm{~m}^{3}\right)$ Cubipod units were manufactured and stacked in the San Andrés breakwater block yard. The production rate per vertical mold was similar to conventional cubes (2 units/day). The high structural strength of massive Cubipod CAUs allowed a multi-layer stacking at the block yard (five layers) with handling safety and efficiency similar to conventional cubic block yards.

Realistic small-scale 3D placement tests were carried out in the UPV wave basin, at 1/36 scale, using a small-scale crawler crane with pressure clamps similar to that used at prototype scale. Different optimum placement grids were found for the straight trunk, curve trunk and roundhead. The curved trunk and roundhead required special progressive grids which depended on the dimensionless curvature. 
Small-scale tests indicated that bottom armor layers on quarrystone were better placed than the upper armor layer placed on Cubipods with lower porosity for the bottom layer.

\section{ACKNOWLEDGMENTS}

The authors received logistic and financial support from the Port Authority of Malaga and the CDTI (CUBIPOD Project). Debra Westall revised the manuscript.

\section{REFERENCES}

Corredor, A., R. Torres, J.V. Miñana, E. Fernández, C.F. Menéndes, M. Santos, M.E. Gómez-Martín, R. Goumy, and J.R. Medina. 2008. CUBÍPODO: Estudios de estabilidad hidráulica $2 D$ y 3D, estudio del remonte y rebase, diseño del encofrado y ensayos de caída de prototipos. Libro del III Congreso Nacional de la Asociación Técnica de Puertos y Costas, Puertos del Estado, 187-211 (in Spanish).

Dupray, S. and J. Roberts. 2009. Review of the use of concrete in the manufacture of concrete armour units. Proceedings of Coasts, Marine Structures and Breakwaters 2009, ICE, Thomas Telford Ltd., Vol 1, 260-271+298-299.

Gómez-Martín, M.E. and J.R. Medina. 2007. Cubipod concrete armor unit and heterogeneous packing. Proceedings of $5^{\text {th }}$ Coastal Structures International Conference, World Scientific, 140-151.

Gómez-Martín, M.E. and J.R. Medina. 2008. Erosion of cube and Cubipod armor layers under wave attack. Proceedings of $31^{\text {st }}$ International Conferecne on Coastal Engineering, ASCE, 3461-3473.

Medina, J.R., M.E. Gómez-Martín and A. Corredor. 2010a. Influence of armor unit placement on armor porosity and hydraulic stability. Proceedings of $32^{\text {nd }}$ International Conferecne on Coastal Engineering, ASCE, Paper No. 255/structures 41.

Medina, J.R., M.E. Gómez-Martín, A. Corredor and M. Santos. 2010b. Diseño de diques en talud con el manto principal de cubípodos. Revista de Obras Públicas, Colegio ICCP, Madrid. 157 (3515): 37-52 (in Spanish).

Medina, J.R., M.E. Gómez-Martín, A. Corredor, R. Torres, J.V. Miñana, E. Fernández, C.F. Menéndez and M. Santos. 2011. Prototype drop tests of cube and Cubipod armor units. Journal of Waterway, Port, Coastal and Ocean Engineering, ASCE, 137(2): 54-63. 